No Gifts from Chance 
Book Five

Louann Atkins Temple Women \& Culture Series

Books about women and families, and their changing role in society 
Shari Benstock

No Gifts from Chance

A Biography of Edith Wharton 


\section{FOR B.B.}

The Louann Atkins Temple Women \& Culture Series is supported by Allison, Doug, Taylor, and Andy Bacon; Margaret, Lawrence, Will, John, and Annie Temple; Larry Temple; the Temple-Inland Foundation; and the National Endowment for the Humanities.

Copyright (C) 1994 by Shari Benstock

All rights reserved

Printed in the United States of America

First University of Texas Press edition, 2004

Requests for permission to reproduce material from this work should be sent to Permissions, University of Texas Press, P.O. Box 7819, Austin, TX 78713-7819.

$@$ The paper used in this publication meets the minimum requirements of ANSI/NISO Z39.48-1992 (R1997) (Permanence of Paper).

\section{Library of Congress Cataloging-in-Publication Data}

\section{Benstock, Shari, 1944-}

No gifts from chance : a biography of Edith Wharton / Shari Benstock.1st University of Texas Press ed.

$$
\text { p. } \mathrm{cm} \text {. }
$$

Originally published: New York : Scribner's, c1944.

Includes bibliographical references (p. ) and index.

ISBN 0-292-70274-4 (pbk. : alk. paper)

1. Wharton, Edith, 1862-1937. 2. Authors, American-20th centuryBiography. 3. Women intellectuals-United States-Biography.

4. Americans-France-History-20th century.

5. World War, 1914-1918-War work-France. I. Title.

$$
\begin{gathered}
\text { PS3545.H16Z595 } 2004 \\
813^{\prime} .52-\mathrm{dc} 22 \\
\text { [B] }
\end{gathered}
$$

